DOI: 10.30525/978-9934-588-61-7-37

Ovsak O. P. Candidate of Economic Sciences, Associate Professor, Associate Professor at the Department of Management of Foreign Economic Activity of Enterprise National Aviation University

Liskovich N. Yu. Postgraduate Student of the Department of Management of Foreign Economic Activity of Enterprise National Aviation University

\title{
METHODICAL COMPONENTS OF ESTIMATION AND PROVISION OF STRATEGIC POSITIONING OF AIR TRANSPORT ENTERPRISES OF UKRAINE
}

\section{Summary}

The article is devoted to the study of the features of strategic positioning of air transport enterprises, which are due to the specifics of air transport services themselves, as well as the peculiarities of their organizational, legal and economic support. The competition of airlines in the provision of international flights is due to the concluded interstate agreements on air communication, as well as the processes of liberalization of the airspace. The strategic position of the air transport company is synthesizing by its nature, it combines the positions of its product, brand and aviation business. The methodical toolkit of definition of a strategic position of the air enterprise on the basis of calculation of indices of its competitive advantages on the list of the defined competences based on branch and functional features of activity of air transport enterprises is offered. The tools of state support of airlines and air transport infrastructure enterprises of Ukraine to ensure their acquisition of competitive advantages for the maintenance and increase of passenger traffic are substantiated.

\section{Introduction}

The strategic positioning of air transport enterprises has a number of significant features, which are primarily due to the peculiarities of the 
provision of air transport services. Air transport activities are carried out by airlines and airports. Direct air transportation is carried out by aircraft of airlines that perform regular, non-scheduled, passenger, cargo, business and other flights. Airports accept both domestic and international flights of national and foreign airlines. They are also engaged in the organization and implementation of shipments of passengers, cargo and mail.

Usually, the admission of foreign airlines to international flights to a particular country is based on bilateral agreements between the two countries. These agreements define air carriers from both countries and all commercial operating conditions of airlines. In essence, such agreements act as a barrier to airlines entering a particular aviation market. Without no doubt such agreements significantly restrict competition in the air transportation markets. Therefore since 1990 the processes of liberalization of aviation with the aim of market development has firstly began in the United States and then in Europe and around the world [4]. The liberalization of air transportation embodies the expansion of the established rules of air traffic regulation in the Chicago Convention signed in 1944 and the creation of special aviation regimes which are called «open skies». This regime is implemented between the EU countries, and has been called the «European Common Aviation Area» (ECAA). The process of regulatory aspects' harmonisation for the signing of the ECAA Agreement between the EU and Ukraine is currently underway.

Following the implementation of the ECAA Agreement between the EU and Ukraine, the regular international traffic to Ukraine and an increase in the number of flights of foreign airlines to Ukraine are expected, which accordingly to the experts will help to reduce the air fares, will increase the competition and the quality of air services $[2 ; 11 ; 13]$. Taking into account the high competitiveness of the European air carriers, experts fear that due to the weak purchasing power of Ukrainians, high fuel costs at the Ukrainian airports and some other factors domestic airlines will find it difficult to compete with foreign ones in both domestic and the European air markets.

However, the liberalization of Ukraine's airspace is not in essence a goal but a mean of ensuring Ukraine's integration into the world airspace. Therefore, an important area of research is a development of methodological components for assessing and provision the strategic positioning of air transport enterprises of Ukraine to ensure sustainable development of national aviation enterprises and the state as a whole.

\section{Part 1. Strategic positioning as a component of strategic management of aviation enterprises}

Many well-known researchers have focused their work on the study of theoretical and practical aspects of strategic positioning of goods: J.N. Kapferer [10], J. Trout and E. Rice, J.J. Lamben, O.V. Zozulov, S. Dibba, G. Huley, D. Aaker [1], C. Crawford [5], R. Moborn, W. Kim [14], F. Kotler [10], Y.Pohorelov, K. Belousova [18], I. Perevozova, I. Andriushchenko, M. Vysotska, A. Vasyliev, L. Krivorotenko [19], 
M. Porter [21], T. Prymak [24], A. Slivotski [23] and others. Thus, F. Kotler in [11] proved that the strategic position of the enterprise is determined by the combined influence of such aggregates as strategic potential and strategic climate. Based on their ratio, he singled out such varieties as a strong strategic position, a strategic position of untapped opportunities, a neutral and weak strategic position. He also distinguished the strategic positions of the enterprise: by attribute (by specific indicators), by competitive position, by level of application (best product for specific purposes), by consumer (product best for a certain category of consumers), and by competitor, by product category ( product - a leader in a particular category of goods) and the ratio of «price - quality» [10].

In his works, in particular in [21], M. Porter argued that the strategic position of the enterprise depended on his chosen model of behavior, which was formed on the basis of certain principles governing the internal structure, interaction of the enterprise with the business environment, ways to attract, combine and use resources. He distinguished the directions of strategic positioning of the enterprise: the breadth of the range, the needs of a particular segment of consumers, focused on access to a particular category of consumers through a combination of different activities, which allowed to meet the needs at the lowest cost.

Thus, positioning is strategic for the enterprise, as it aims to form long-term loyalty to the product, brand, enterprise and business as a whole. The strategic position of the company is inherently synthesizing, as it combines the positions of product, brand and business. The strategic position of the enterprise is the result of strategic management, due to the skillful use of all factors to implement the chosen strategy.

T. Prymak in her work [24] proposes to choose the main criteria for the classification of positioning strategies: by product, by manufacturer, by consumer, by service, by participation in public life and social movements. She emphasizes that positioning can be carried out on one, two, three grounds. The choice of positioning strategy depends on the specifics of each company and the products it produces. Accordingly, when studying the components of the strategic positioning of air transport enterprises of Ukraine, we focused on the industry characteristics that affect the possibilities of their strategic positioning.

Environmental factors determine the specifics of relationships and interactions of business entities in the field of air transport. Methods of strategic management of air transport companies should take into account the impact and direction of these factors. They should be taken into account when developing a strategy for the development of airports and airlines to achieve high performance in the air transport industry.

In addition to external factors, the strategic positioning of an air transport enterprise is based on the existing internal environment, business processes and other internal factors, which together with the internal environment of domestic and foreign competitors form competitive advantages or weaknesses of such aviation enterprise. After all, the existing competitiveness of airlines, 
the competitiveness of their products - air transportation, determined by their types, safety, quality, tariffs, etc., is the starting point for forming the concept of strategic positioning of airlines for the future, which, accordingly, relies on existing competitive advantages. The latter can be defined as components, elements of the external or internal environment of the enterprise, in which it has an advantage over competitors.

The study of the nature of the origin of the competitive advantages of air transport enterprises, in particular airlines, in modern business conditions, allows to determine that they are formed:

- at the market level (network of routes, competition and integration of airlines in spatial terms);

- at the product level (competitiveness of air transportation services, taking into account their types, flight safety, quality, tariff policy, etc.);

- on the basis of the airline's business model, which determines the way of using production resources and determines the application of technologies for the organization of aircraft operation, the sale of transportation, etc.

- by involving measures of state regulation [7;8].

Thus, the macroeconomic factors influencing the activities of domestic aviation enterprises, which have a stimulating function of influencing the development of the aviation sector of Ukraine, include: GDP growth of Ukraine and other countries, macroeconomic stability, emerging market segments, increasing national currency exchange rate, population growth, personal income and effective demand of the population, reducing the tax burden on aviation business entities, the development of aviation liberalization. Accordingly, the macroeconomic factors that hinder the development of Ukraine's aviation sector include: decline in national and world production, the presence of military and political conflicts in the country, devaluation of the national currency, fluctuations in the national currency, rising travel costs, declining personal income and effective demand. tax burden on aviation business entities, etc. The global factors of positive impact on the activities of domestic enterprises include integration trends that contribute to the involvement of domestic aircraft manufacturers and carriers in international projects. Global factors limiting the development of domestic aviation enterprises include pandemics, and in order to overcome it, states are forced to suspend passenger traffic, impose restrictive quarantine measures that freeze the business activity of airlines. Accordingly, along the chain, the activity of enterprises - contractors, providing the activities of the aviation business, from airports to aircraft manufacturers - decreases and sometimes ceases.

Among the factors of microeconomic impact that constrain the activities of domestic airlines should be mentioned such as: significant monopolization of the air transportation market and its reduction, outdated fleet of aircraft and restrictions on its renewal, including financial, lack of financial mechanisms to attract new domestic aircraft, in particular on the terms of leasing, access to the domestic market of foreign suppliers of ground equipment and service devices at airports, lack of available borrowed capital, closure of domestic airports, etc. [7]. Accordingly, the factors of microeconomic impact that 
stimulate the activities of domestic aviation enterprises include: creating conditions for airlines timely renewal of aircraft fleet, increasing demand for domestically produced aircraft, modernization of aircraft, modernization of ground equipment and service facilities at airports, cheaper capital, modernization and development of airports.

\section{Part 2. Toolkits for assessing the strategic position of the air transport company}

To ensure the choice of tools for strategic positioning of the airline, it is necessary to assess the current state of strengths and weaknesses of its business, which should be done using SWOT-analysis ( $\mathrm{S}$ - Strength; W Weakness; O - Opportunities; T - Threats). It is chosen because it obeys the basic principle: the strategy must ensure the correct correspondence of the internal capabilities of the enterprise (its strengths and weaknesses) to the external situation (due, in part, to its capabilities and threats). Since SWOTanalysis is a tool designed to determine the strategic situation of the business structure, the sequence of its implementation involves the identification and analysis of external opportunities and threats, analysis of internal strengths and weaknesses of the enterprise and development of strategic decisions based on this. The analysis of the external environment of the air transport enterprises of Ukraine reveals the main opportunities that can be used by the airline and the airport, and the main threats to eliminate the aviation companies must develop preventive measures (Figure 1).

The next step in the SWOT-analysis is the analysis of the internal environment of air transport enterprises, i.e., identification of its strengths that contribute to the opportunities provided by the external environment, and weaknesses that need to be «protected» from possible threats to the environment (Figure 2).

The analysis of Figures 1 and 2 shows that the external environment of air transport enterprises of Ukraine assumes the existence of a large number of opportunities available to enterprises and the dangers that may be experienced by the airline if it wants to achieve these opportunities, higher results.

The results of the analysis are summarized in a matrix (Figure 3 and Figure 4), which allows to establish relationships between the studied factors and to suggest possible strategic solutions. 


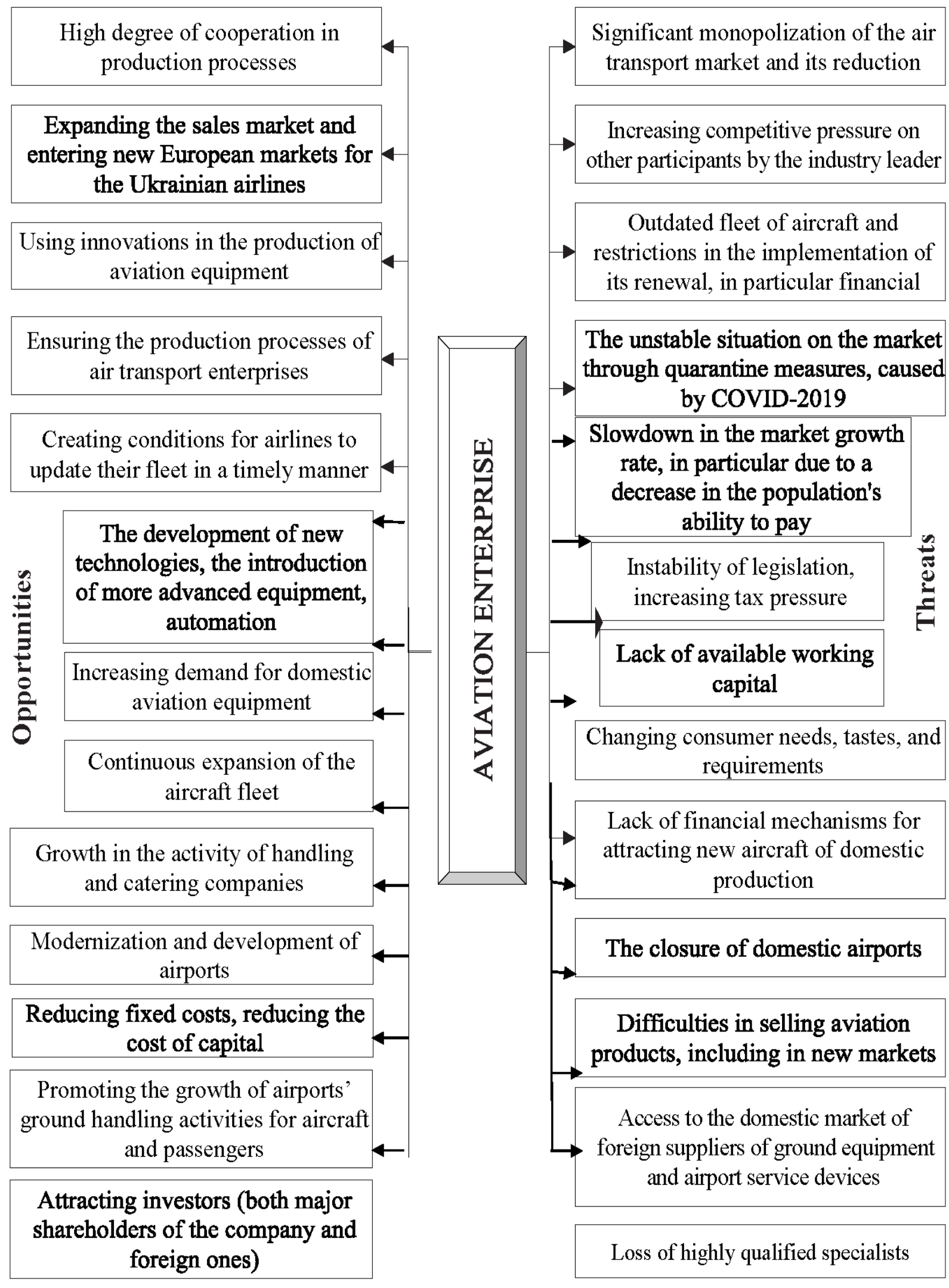

Figure 1. External opportunities and threats affecting the activities of Ukraine's aviation enterprises 


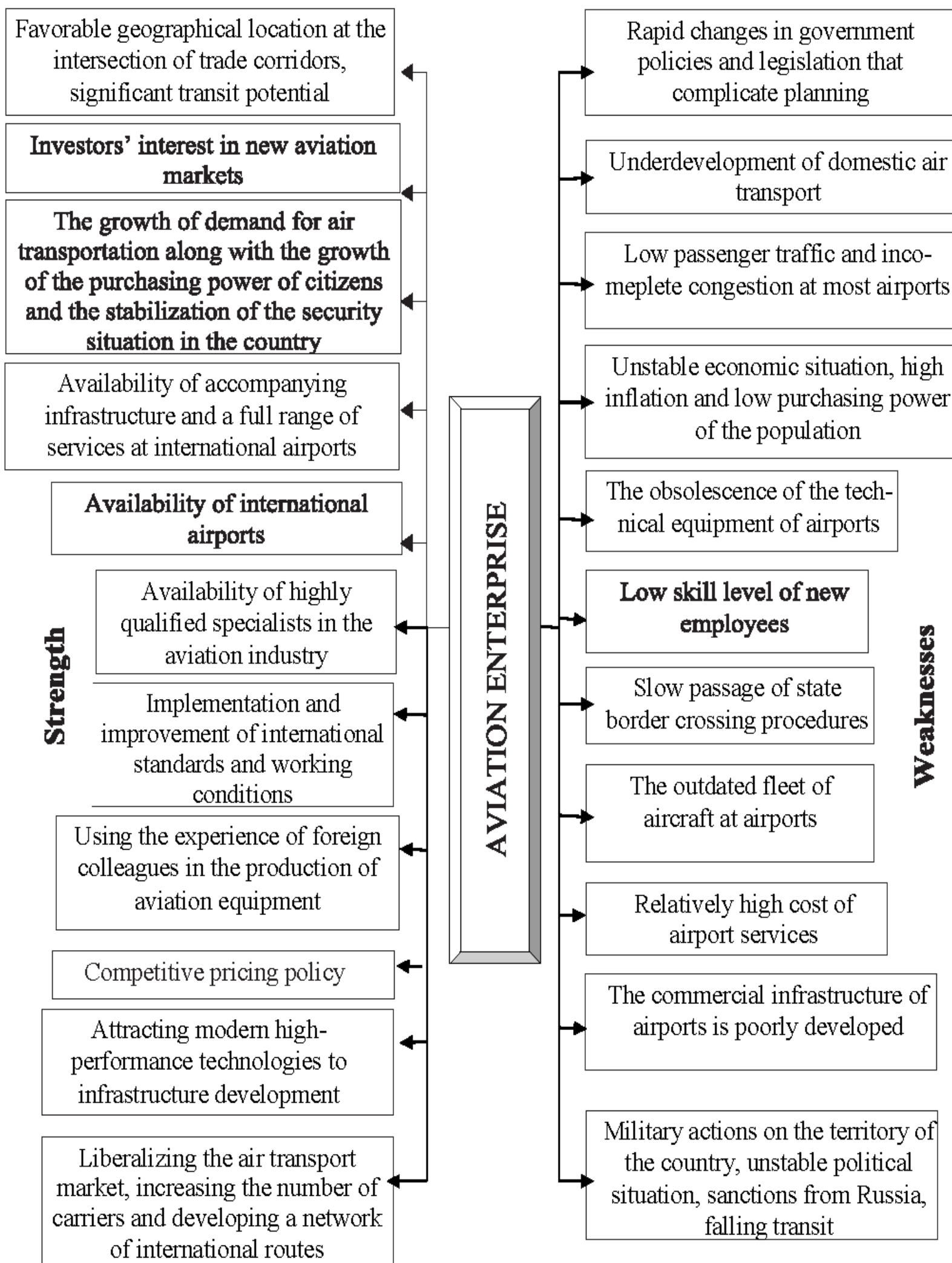

Figure 2. Strengths and weaknesses of Ukraine's air transport enterprises 
Internal environment

\section{External environment}

\begin{tabular}{|c|c|}
\hline Strengths (S) & Weaknesses (W) \\
\hline $\begin{array}{l}\text { - Availability of the } \\
\text { base airport; } \\
\text { - Available oppo- } \\
\text { rtunities for infrast- } \\
\text { ructure expansion } \\
\text { without significant } \\
\text { additional costs; } \\
\text { - A large share of } \\
\text { international air } \\
\text { transport; } \\
\text { - Availability of a } \\
\text { network of } \\
\text { transcontinental flights. }\end{array}$ & $\begin{array}{l}\text { - High level of formalities } \\
\text { when crossing the state } \\
\text { border, which prevents an } \\
\text { increase in transfer } \\
\text { passenger traffic; } \\
-\quad \text { Insufficiently } \\
\text { developed transfer } \\
\text { infrastructure; } \\
-\quad \text { Relatively high cost } \\
\text { of services provided; } \\
-\quad \text { Insufficient } \\
\text { development of available } \\
\text { aviation infrastructure. }\end{array}$ \\
\hline SO- strategy & WO-strategy \\
\hline $\begin{array}{l}- \text { Encourage air-lines } \\
\text { to open new in- } \\
\text { ternational flights and } \\
\text { maintain existing routes } \\
\text { - Cooperation with } \\
\text { airlines in order to } \\
\text { increase the transfer } \\
\text { passenger traffic } \\
- \text { Benchmarking } \\
\text { among the European } \\
\text { airlines }\end{array}$ & $\begin{array}{l}\text { - Increase of labor } \\
\text { productivity } \\
- \text { Implementation of } \\
\text { outsourcing } \\
- \text { Using the strategy of } \\
\text { cooperation to maintain a } \\
\text { position in the air } \\
\text { transportation market; }\end{array}$ \\
\hline ST-strategy & WT-strategy \\
\hline $\begin{array}{l}\text { - Creation of } \\
\text { infrastructure for } \\
\text { servicing transfer } \\
\text { passengers } \\
- \text { Introduction of new } \\
\text { services to increase } \\
\text { revenue; } \\
- \text { Saving the network } \\
\text { of existing routes }\end{array}$ & $\begin{array}{l}\text { - Use of protective, niche } \\
\text { strategies for the sale of } \\
\text { transportation and } \\
\text { provision of aviation } \\
\text { services; } \\
\text { - Using a strategy to } \\
\text { adapt to the market } \\
\text { situation; } \\
\text { - Opitimization of the } \\
\text { route network in order to } \\
\text { minimize costs. }\end{array}$ \\
\hline
\end{tabular}

Figure 3. Extended SWOT-analysis matrix of an airline 


\section{Internal environment}

External environment

\begin{tabular}{|l|}
\hline Strengths (S) \\
\hline- Favorable \\
geographical position of \\
the country at the \\
intersection of internationa
\end{tabular}

trade corridors, significant transit potential

- Availability of accompanying infrastructure and a full range of services at international airports - availability of basic airlines that provide transfer passenger traffic to the airport,

- Development of nonaviation activities

\begin{tabular}{|c|c|c|}
\hline Opportunities (O) & SO-strategy & WO-strategy \\
\hline $\begin{array}{l}- \text { Liberalizing the air } \\
\text { transport market, } \\
\text { increasing the number of } \\
\text { carriers and developing a } \\
\text { network of international } \\
\text { routes } \\
-\quad \text { Availability of anchor } \\
\text { carriers at some airports } \\
- \text { The growth of demand } \\
\text { for air transportation along } \\
\text { with the growth of } \\
\text { purchasing power of } \\
\text { citizens and stabilization of } \\
\text { the situation in the country }\end{array}$ & $\begin{array}{l}\text { - Cooperation with } \\
\text { airlines in terms of } \\
\text { encouraging the opening } \\
\text { of new flight directions } \\
\text { and maintaining existing } \\
\text { routes } \\
-\quad \text { Simplification of } \\
\text { border crossing procedures } \\
-\quad \text { Improving the level of } \\
\text { passenger service, primarily } \\
\text { in terms of providing non- } \\
\text { aviation services } \\
-\quad \text { The growth of staff } \\
\text { skills, improvement of } \\
\text { techno-logical processes } \\
\text { will make it possible to } \\
\text { keep up with the growth } \\
\text { of the market }\end{array}$ & $\begin{array}{l}\text { - Supporting the } \\
\text { development of related } \\
\text { infrastructure and } \\
\text { socially important } \\
\text { facilities } \\
-\quad \text { Reducing public } \\
\text { spending on infrastructure } \\
\text { maintenance, spending on } \\
\text { inefficient management } \\
-\quad \text { Ensuring the } \\
\text { operational efficiency of } \\
\text { infrastructure facilities, } \\
\text { using modern, efficient } \\
\text { technologies, simplifying } \\
\text { and optimizing } \\
\text { management and } \\
\text { financial control; }\end{array}$ \\
\hline Threats (T) & ST- strategy & WT-strategy \\
\hline $\begin{array}{l}- \text { Reduction or lack of } \\
\text { government interest in } \\
\text { airport modernization } \\
-\quad \text { Increasing the level of } \\
\text { requirements for airport } \\
\text { infrastructure and the need } \\
\text { for additional investment } \\
-\quad \text { Strengthening the } \\
\text { position of foreign } \\
\text { competing airports } \\
-\quad \text { Development of } \\
\text { alternative high-speed } \\
\text { transport }\end{array}$ & $\begin{array}{l}\text { - Unstable economic } \\
\text { situation, high inflation } \\
\text { and low purchasing } \\
\text { power of the population } \\
-\quad \text { Complexity of doing } \\
\text { business } \\
\text { - The need for } \\
\text { significant investment in } \\
\text { infrastructure } \\
\text { modernization }\end{array}$ & $\begin{array}{l}\text { Economic crisis, } \\
\text { falling purchasing power } \\
\text { of the population } \\
-\quad \text { Poorly developed } \\
\text { commercial } \\
\text { infrastructure of the } \\
\text { airports } \\
-\quad \text { The emergence of } \\
\text { new competitors, low } \\
\text { level of service and high } \\
\text { prices will worsen the } \\
\text { competitive position; }\end{array}$ \\
\hline
\end{tabular}

Figure 4. Extended SWOT-analysis matrix of an aiport 
Based on the results of the analysis, it is possible to determine priorities in the allocation of resources of a particular aviation business enterprise with regard to external opportunities and dangers, identify the main causes of negative impact on its activities, which will allow top management to offer strategic alternatives for sustainable development. Using the above tools makes it possible to determine the market situation of a particular national airline or airport. As an indicator of comparison of the competitive position of airlines, we consider it appropriate to use a generalizing indicator that takes into account the value of scoring the impact of each factor of market opportunity or threat, the weight of the factor's contribution to the overall indicator and the probability of occurrence.

$$
\begin{aligned}
& E M O_{i}=w_{i} \times p_{i} \times d_{i}, \mathrm{i}=1 \ldots \mathrm{n}, \\
& E M T_{j}=w_{j} \times p_{j} \times d_{j}, \mathrm{j}=1 \ldots \mathrm{n},
\end{aligned}
$$

where $\mathrm{EMO}_{\mathrm{i}}-$ general assessment of the influence of the $\mathrm{i}$-th or $\mathrm{j}$-th factor of market opportunity);

EMTi - general assessment of the impact of the i-th factor of market threat (market threats);

$w_{i}, j$ - coefficient of weight of the $i$-th or $j$-th factor;

$p_{i}, j-$ probability of occurrence of the $i-t h$ or $j$-th factor;

$\mathrm{d}_{\mathrm{i}}, \mathrm{j}$ - the degree of manifestation of the i-th factor; the degree of manifestation of the i-th factor;

$\mathrm{n}-$ the number of factors.

The sum of the received general assessments of the influence of the i-th factors will make the general indicator of potential market threats or opportunities - EMT or EMO:

$$
\begin{aligned}
& I M O=\sum_{i=1}^{n} E M O_{i} \\
& \mathrm{IMT}=\sum_{\mathrm{j}=1}^{\mathrm{n}} \mathrm{IMT}_{\mathrm{j}}
\end{aligned}
$$

where IMO - general indicator of potential market opportunities;

IMT - general indicator of potential market threats.

Managers responsible for decision-making in the air transport industry, heads of airlines, airports, and specialists, who are mainly representatives of various divisions of airlines, airports should be involved as experts. To compare the obtained scores of market threats and market opportunities of strategic positioning of the aviation company, we propose to calculate an integrated indicator of market access. It should show the degree of advantage of market opportunities over threats and will characterize the degree of prospects of the airline in the market:

$$
I_{M A}=I M O / I M T
$$

where IMA - an integrated market access indicator. 
An increase in the value of this index will indicate an improvement in the ratio of market opportunities and threats, and thus an increase in the airline's access to the market.

The proposed tools allow us to assess the market position of a particular airline, such as an airline, even in dynamics, but the task remains to compare its position relative to other airlines, i.e., taking into account the competitive environment.

In this regard, we consider it appropriate to focus on the use of a competency-based approach to the formation of the strategic position of the airline.

As you know, the competencies of the enterprise as a source of competitive advantage are used in the competitive and strategic positioning of the enterprise $[11 ; 13 ; 23 ; 26]$. The use of such an approach makes it possible to determine the strategic position of the airline or airport, allows to systematize their competitive advantages. Based on the results of the assessment of the factors influencing the strategic positioning of air transport enterprises (Table 1 or Figure 1) and the development of extended SWOT-matrices of analysis of airlines and airports (Figure 3 and Figure 4), we have formed parameters for building matrices of airline and airport competencies, their competitive advantages, in accordance with industry and functional features.

Thus, the main competencies of the airport include: airport class, developed airport infrastructure, the presence of a basic airline that provides transfer passenger traffic to the airport, transparent and flexible system of motivation of airlines, the availability of effective business processes, high security and quality of service, availability of the highly qualified personnel, effective communications, relations with suppliers, development of non-aviation activities, availability of reliable sources of airport development. In turn, the list of key competencies of the airline should include the following: developed network of routes, punctuality of flights, modern fleet, the ability to replace and expand quickly, the availability of efficient business processes, high safety and quality of service, expanded network of sales, high adaptability, availability of highly qualified personnel, effective communications, connections with suppliers, availability of reliable sources of development of the airline, active position of owners in ensuring its development. Thus, the strategic positioning of national airlines is based on their internal competencies, as well as external receptive factors for the success of the airline. Based on the comparison of the competencies of a national airline with the competencies of foreign airlines competing with it in the market of international air transportation, it is possible to build a matrix of competitive advantages of such a national airline. It clearly demonstrates and allows to determine the directions of benchmarking of the national airline, based on the results of pairwise comparisons with competing airlines, including foreign ones. A similar approach should be used for benchmarking of domestic airports.

As a result of the assessment of competencies, it is possible to determine the competitive advantages of the airline in the air transportation market. 
Comparison of the calculated values of the competencies of an airline or airport with the competencies of a competitor forms an index of competitive advantage of such an airline (IC) for a certain competence. It is calculated by the formula:

$$
I_{C A A}=A_{A C} /_{A_{C A C}}
$$

Aac - assessment of the competence of the airline;

Acac - assessment of the competence of the airline - a competitor.

If the value of the index of competitive advantages of a certain national airline (IC) for a certain competence exceeds 1, then its competence is higher than the corresponding competence of the competitor airline. The same sequence of actions is carried out for the entire list of competencies defined for a particular type of air transport company. If the IC is less than 1, the relevant competence of the airline has a lower rating than that of the competitor airline, which weakens the competitive position of such airline. Thus, the formation of matrices of competitive advantages of the airline or airport allows to determine their strengths and weaknesses in a competitive environment.

\section{Part 3. Providing conditions for the leading strategic positioning of national airlines}

In order to develop regulatory decisions by the State Aviation Administration of Ukraine to support national aviation enterprises in the context of gradual liberalization of the Ukrainian aviation space based on the removal of restrictions in bilateral interstate agreements, it is advisable to expand the analysis tools to systematize national airlines and airports into certain strategic groups.

In international publications, there are published quite a few articles on the definition of strategic groups of enterprises, individual airlines. Thus, researchers Murthi B.P.S., Rasheed A.A., Goll I. in the source [13] revealed the features of using the latent class regression model to identify strategic groups of American airlines. But, unfortunately, given the state of corporate relations, such an approach to identify strategic groups in the air transportation market of Ukraine cannot be used. This is due to the lack of public information on the financial statements of airlines. Only 2 airlines Ukraine International Airlines (UIA) and Dniproavia PJSC - are joint-stock companies that publish their financial statements. Other airlines in their organizational and legal form are limited liability companies and do not publish their reports openly.

More often, experts in the transport aviation industry advise to use the approach of M. Porter, according to which they form strategic groups of competing firms that use similar competitive approaches and market positions. According to this methodological approach, a study was conducted [9] (Kling J. A., Smith K. A. 1995) to identify strategic groups of American airlines. 
In our study, we also focus on the methodological approach of M. Porter (Porter M. 1980) [22] and emphasize the feasibility of using cluster analysis to identify strategic groups of both national airlines and national airports. Cluster analysis should be based on the study of external indicators based on the internal environment of the airline, business processes and culture, to identify strategic groups of airlines and airports in terms of their place in the air transport market of Ukraine) and their ability to compete in international transport - foreign airlines.

We consider it expedient to choose the following criteria for identifying strategic groups of national airlines: type of transportation (passenger, cargo, mixed), types of air transportation (regular, charter, business aviation, aviation works), volume of passenger traffic, cargo, mail (respectively to ranking of blocks of ranges); number of flights (according to the ranking of blocks of ranges); market share (according to the ranking of blocks of ranges); punctuality of airlines (according to the ranking of blocks of ranges); airline business model (network, regional, low-cost, business aviation, aviation services), the presence of corporate ties among airlines (related parties). According to the results of the cluster analysis for national airlines with leading positions in a certain strategic group it is necessary to compile, form a «matrix of competencies of the airline» to determine competitive advantages (and weaknesses) compared to leading foreign airlines operating flights to Ukraine.

Accordingly, the list of criteria for identifying strategic groups of national airports is formed on the basis of the parameters of the matrix of airport competencies, which were discussed in the previous chapter.

The analysis of sources showed that simultaneously with the deepening and expansion of the liberalization of the airspace of the countries, the practice of providing state support to national airlines is spreading. Such processes have taken place and are taking place from time to time in both the United States and the European Union [3], [16]. Government support in the form of subsidies, repurchase of shares in the share capital is provided during periods of crisis of such airlines, which is often associated with the actions of stronger competitors and economic, financial and other crises, sometimes global in nature. The latter certainly includes the economic crisis caused by the restriction of business activity of air transport companies due to the adoption of forced anti-pandemic measures by states (COVID19). Other tools are also used. For example, the European Union uses leverage to protect airlines from the financial consequences of a global coronavirus pandemic to ensure the resilience of airlines. Thus, «Eurocontrol» has decided to postpone the payment of bills for airlines provided during February-May 2020 by the AIE to mid-2021 [6].

In particular, important areas of ensuring the competitive strategic positioning of domestic airlines are the introduction of a zero rate of value added tax in the taxation of domestic air transportation services. This will stimulate the volume of domestic air traffic (according to 2019, the volume of domestic air traffic of passengers is less than $10 \%$ of their total value). For 
Ukrainian airlines, this will reduce the cost of these flights because they have never been profitable for them, more often provided passenger traffic on international flights (known hub model «hubs and spokes»), as well as «overtaking» aircraft to other domestic airports.

As in the EU countries fuel for air transportation is not subject to VAT, it is advisable to introduce a zero VAT rate on the sale of kerosene for the domestic market. This will help to increase the competitiveness of domestic airlines in the international air transportation market, and will work on a favorable strategic positioning of domestic airports, where you can refuel at a competitive price.

The implementation of the proposed measures will provide: reducing the cost of air transportation, reducing air fares, attracting additional passenger traffic, creating favorable competitive conditions for domestic airlines for attractive / competitive strategic positioning in the international air transport market [18]. At the same time, a necessary component is to ensure the development of Ukraine's air transport infrastructure (airport, multimodal complexes, etc.), to enable an increase in passenger traffic, in particular on the basis of public-private partnership. This will ultimately strengthen the strategic positioning of both domestic airports and domestic airlines and work to ensure economic growth in Ukraine, including through the multiplier effect that air transport has on the economy [17].

\section{Conclusions}

Strategic positioning of aviation enterprises is carried out in order to preserve, form and strengthen their competitive advantages in the current conditions of expansion and deepening of the processes of regional integration and globalization. Depending on the strategic choice in creating competitive advantages, different emphasis is placed on the management of the enterprise. That is, strategic positioning affects the management processes of the enterprise depending on its strategic choice to create and develop competitive advantages. The strategic position of the air transport company is synthesizing by nature, as it combines the positions of its product, brand and business.

The proposed methodological tools allow to determine the strategic position of the airline based on the calculation of indices of its competitive advantages on the list of certain competencies inherent in these types of enterprises. As a result of the assessment of the factors influencing the strategic positioning of air transport companies and the development of advanced SWOT-matrices of analysis of airlines and airports, we have developed parameters for building matrices of competencies of airlines and airports to determine their competitive advantages, taking into account their industry and functional features.

We believe that in the face of the negative impact of global and macroeconomic factors, there is a growing need to use the tools of state regulation to ensure current financial stability, as well as the formation of competitive strategic positioning of domestic aviation companies. Given the 
economic crisis caused by the restriction of business activity of air transport enterprises in connection with the adoption of forced anti-pandemic measures (COVID19), it is necessary to provide state support to airlines and air transport infrastructure enterprises of Ukraine, including airport complexes, to provide them with competitive advantages to increase passenger traffic. Prior to concluding an agreement on a common aviation area, liberalization should be carried out in the direction of expanding traffic in Ukraine's interstate agreements on air services, while implementing state regulatory measures necessary to improve the strategic positioning of domestic air transport companies. The main goal of the liberalization of Ukraine's aviation space is to increase the welfare and ensure economic growth of Ukraine. But such a goal can be achieved only with the growth of passenger traffic at the Ukrainian airports and ensuring the active participation of domestic airlines in the market, through the involvement of government regulation tools that will ensure a proper stable competitive position.

\section{References:}

1. Aaker D. (2007) Stratehycheskoe rynochnoe upravlenye [Strategic market management]. Translated into English under. ed. S.G. Bozhuk. SPb.: Peter, 496 p.

2. Aviatsiynyy vektor skhidnoho partnerstva: otsinka prohresu Ukrayiny, Moldovy ta Hruziyi u nablyzhenni do aviatsiynoho zakonodavstva YES (2017) [Aviation Partnership Aviation Vector: Assessment of Ukraine, Moldova and Georgia's progress towards approximation to EU aviation legislation]. Available at: https://europewb.org.ua/wpcontent/uploads/2017/12/print_zvit_The-Eastern-Partnership-Air-Transport-Vector_EWB.pdf (accessed 25 May 2020).

3. Budd T. (2015). The end of liberalization? Selected papers from the 4th European Aviation Conference (EAC), UK, Journal of Air Transport Management.Vol. 74, January 2019, pages 20-21. Available at: https://doi.org/10.1016/j.jairtraman.2018.09.009 (accessed 25 May 2020).

4. Button K.J., Taylor S.Y. (2000): International Air Transportation And Economic Development, 40th Congress of the European Regional Science Association: «European Monetary Union and Regional Policy», August 29 - September 1, 2000, Barcelona, Spain, European Regional Science Association (ERSA), Louvain-la-Neuve. Available at: https://www.econstor.eu/bitstream/10419/114969/1/ERSA2000_483.pdf. (accessed 26 May 2020)

5. Crawford C.M. (1985) A New Positioning Typology. The journal of product innovation management. Vol. 2. P. 243-253. - Available at: http://onlinelibrary.wiley.com/ doi/10.1111/ 1540-5885.240243/abstract (accessed 26 May 2020)

6. GTP editing team. (2020) Covid-19: Airlines Allowed to Delay Payments of Air Traffic Control Charges. Available at: https://news.gtp.gr/2020/04/08/covid-19-airlinesallowed-delay-payments-of-air-traffic-control-charges/ (accessed 02 June 2020).

7. Liskovich N.Yu. (2019). Competitiveness assessment of aviation infrastructure enterprises of Ukraine. Proceedings of the XV International Scientific and Practical Conference «Modern problems of management» [Suchasni problemy menedzhmentu] October 25. Kyiv: NAU. P. 15-16 Available at: https://nau.edu.ua/site/variables/docs/ docsmenu/nauka/konferencii/2019/ftml/materialy-suchasni-problemy-menedzhmentu-2019.pdf (accessed 26 May 2020)

8. Liskovich N.Yu. (2020). Chynnyky stratehichnoho pozytsionuvannia aviatsiinykh pidpryiemstv Ukrainy [Factors of Ukraine' aviation enterprises strategic positioning]. Proceedings of the XV International Scientific and Practical Conference «Competitive 
model of innovative development of Ukraine's economy» [Konkurentospromozhna model innovatsiinoho rozvytku ekonomiky Ukrainy] April 14 2020. Kropyvnytskyi, Ministry of Education and Science of Ukraine, Central Ukraine. nat. tech. un-ty. - Kropyvnytskyi: CNTU, 2020. - 356 p. Available at: http://dspace.kntu.kr.ua/jspui/bitstream/123456789/ 9724/3/Proceedings-3thISPConf-2020.pdf (accessed 10 June 2020). (in Ukrainian)

9. Kapferer J.-N. (1997). Strategic brand management: creating and sustaining brand equity long term / J.-N. Kapferer. London. Dover, NH, USA: Kogan Page,443p. Available at: http://www.sabairib.com/dl/files/Strategic_Brand_Management.pdf (accessed 28 May 2020)

10. Kling J. A., Smith K. A.(1995) Identifying strategic groups in the U.S. airline industry: an application of the Porter model. Transportation Journal. Vol. 35. No. 226-34. Available at: https://trid.trb.org/view/458134

11. Kotler Ph. (2012). Marketing management / Ph. Kotler, K.L. Keller.Harlow Pearson Education, 2012. 811p. Available at: http://socioline.ru/files/5/283/kotler_keller__marketing_management_14th_edition.pdf (accessed 29 May 2020).

12. Matsenko O.M., Heyets' I. O., Myronova Y. V., Skrypka Y. O. (2018) Stratehichni napryamy liberalizatsiyi povitryanoho prostoru mizh Ukrayinoyu ta YES / [Strategic directions of airspace liberalization between Ukraine and the EU]. Available at: https://essuir.sumdu.edu.ua/handle/123456789/70641 (accessed 29 May 2020).

13. Murthi B.P.S., RasheedA. A., Goll I. (2013). An Empirical Analysis of Strategic Groups in the Airline Industry using Latent Class Regressions. Managerial and Decision Economics. Vol. 34. No 2. P. 59-73.

14. Mykhailychenko K.M. (2014). Pidvyshchennia efektyvnosti derzhavnoho rehuliuvannia rynku aviatsiinykh perevezen Ukrainy $\mathrm{v}$ umovakh aktyvizatsii intehratsiinykh protsesiv z YeS. [Improving the efficiency of state regulation of the air transportation market of Ukraine in terms of intensification of integration processes with the EU]. Stratehiia rozvytku Ukrainy [Development strategy of Ukraine], no. 1, pp. 125-132. (in Ukrainian)

15. Moborn R., Kim W.C. (2016) Stratehiia blakytnoho okeanu. Yak stvoryty bezkhmarnyi rynkovyi prostir i pozbutysia konkurentsii. [Blue ocean strategy. How to create a cloudless market space and get rid of competition]. Kiev. Family leisure club. 384 p. (in Ukrainian)

16. Morrison W.G., Jaap de Wit. (2019) US open skies agreements and unlevel playing fields. Journal of Air Transport Management.Vol. 74, January 2019, Pages 30-38. Available at: https://www.sciencedirect.com/science/article/abs/pii/S0969699718303909

17. Ovsak O.P., Liskovych N.Yu. (2019). Makroekonomichni aspekty vplyvu rozvytku povitryanoho transportu na ekonomiku Ukrayiny [Macroeconomic aspects of the impact of air transport development on the economy of Ukraine]. Black Sea Economic Studies. PU Black Sea Research Institute of Economics and Innovation. Issue 48. 2019. P. 133-141. (in Ukrainian)

18. Ovsak O.P., Liskovich N.Yu., Nazarenko O.P. (2020). Ukraina na shliakhu liberalizatsii aviatsiinoho prostoru. [Ukraine on the path of aviation liberalization]. Infrastruktura rynku [Market infrastructure]. Electronic journal, vol. 40, no. 3-13. Available at: http://www.market-infr.od.ua/journals/2020/40_2020_ukr/3.pdf (accessed 30 May 2020)

19. Pogorelov Y., Belousova K. (2014). Stratehichne pozytsionuvannia pidpryiemstva: zmist poniattia. [Strategic positioning of the enterprise: the content of the concept]. Naukovyi visnyk Poltavskoho universytetu ekonomiky i torhivli [Scientific Bulletin of Poltava University of Economics and Trade], vol. 6, no. 68, p. 95-102. (in Ukrainian)

20. Perevozova I., Andryushchenko I., Vysotska M., Vasyliev A., Krivorotenko L. (2019) Introduction of Strategic Management Technology into the Existing Organizational and Economic Mechanism of the Enterprise. Academy of Strategic Management Journal Volume 18, Special Issue 1, 2019. Available at: https://www.abacademies.org/articles/ 
introduction-of-strategic-management-technology-into-the-existing-organizational-andeconomic-mechanism-of-the-enterprise-8814.html (accessed 25 May 2020)

21. Piermartini R., Rousova L. (2008). Liberalization of Air Transport Services and Passenger Traffic. World Trade Organization. Staff Working Paper ERSD-2008-06 Available at: https://www.wto.org/english/res_e/reser_e/ersd200806_e.pdf (accessed 25 May 2020)

22. Porter M.E. (2008) Competitive Strategy: Techniques for Analysing Industries and Competitors. Available at: https://books.google.com.ua/books?hl=uk\&lr=\&id=Hn1kNE0 OcGsC\&oi=fnd\&pg=PT5\&dq=related:4ARutR7qKgEJ:scholar.google.com/\&ots=KKFPk mihJM\&sig=f4tZvGdhqZmKN3GTt3d1o073ebk\&redir_esc $=\mathrm{y} \# \mathrm{v}=$ onepage \&q\&f=false

23. Prahalad, C. K. (1990). The core competence of the corporation / C. K. Prahalad, G. Hamel // Harvard Business Review. 1990. Vol. 68, no. 3, p. 79-91.

24. Prymak T.O. (2012). Konkurentospromozhna model innovatsiinoho rozvytku ekonomiky Ukrainy [Positioning strategies in marketing theory]. Marketynh i menedzhment innovatsii [Marketing and innovation management]. Available at:http://mmi.fem.sumdu.edu.ua/(accessed 25 May 2020). (in Ukrainian)

25. Slivotski A. (2006) Myhratsyia tsennosty. Chto budet s vashym byznesom poslezavtra? [Migration of values. What will happen to your business the day after tomorrow?]. M.: Mann, Ivanov i Ferber, 2006. 432 p.

26. Tidd J. (2006). From strategic management to strategic competence: measuring technological, market and organization innovation. Joe Tidd. 2nd ed. London: Imperial College Press. 437 p. 